\title{
COMMENTS
}

\section{Forum Non Conveniens and State Control of Foreign Plaintiff Access to U.S. Courts in International Tort Actions}

Laurel E. Miller $\dagger$

Federal courts have virtually closed their doors to foreign plaintiffs pursuing personal injury and products liability claims against U.S. corporations based on injuries incurred abroad. ${ }^{1}$ Those courts have done so by expansively interpreting the federal common law doctrine of forum non conveniens, which permits a court to dismiss a case on the ground that it may be tried more conveniently elsewhere. ${ }^{2}$ Meanwhile, pro-plaintiff tort laws, discovery rules, choice of law rules, contingent fee arrangements, and jury awards continue to attract foreign plaintiffs to U.S. forums. ${ }^{3}$ Thus, foreign plaintiffs increasingly sue in state courts, ${ }^{4}$ where the degree of adherence to the federal forum non conveniens standard varies among states. ${ }^{5}$

$\dagger$ A.B. 1986, Princeton University; J.D. Candidate 1992, The University of Chicago.

${ }^{2}$ See, for example, In re Union Carbide Corp. Gas Plant Disaster at Bhopal, $634 \mathrm{~F}$ Supp 842 (S D NY 1986), aff'd in part, 809 F2d 195 (2d Cir 1987); and Sibaja v Dow Chemical Co., 757 F2d 1215 (11th Cir 1985).

? See Sheila L. Birnbaum and Douglas W. Dunham, Foreign Plaintiffs and Forum Non Conveniens, 16 Brooklyn J Intl L 241 (1990).

- See Russell J. Weintraub, A Proposed Choice-of-Law Standard for International Products Liability Disputes, 16 Brooklyn J Intl L 225, 225-26 (1990); Note, Foreign Plaintiffs and Forum Non Conveniens: Going Beyond Reyno, 64 Tex L Rev 193 (1985). See also Piper Aircraft Co. $v$ Reyno, 454 US 235, 252 n 18 (1981).

- David W. Robertson and Paula K. Speck, Access to State Courts in Transnational Personal Injury Cases: Forum Non Conveniens and Antisuit Injunctions, $68 \mathrm{Tex} \mathrm{L} \mathrm{Rev}$ 937, 940 (1990).

- See Section II. 
In one recent international ${ }^{6}$ tort case, Dow Chemical Co. $v$ Alfaro, ${ }^{7}$ the Texas Supreme Court did not simply diverge from the federal forum non conveniens standard; that court declared that the doctrine does not exist in Texas for wrongful death or personal injury suits. ${ }^{8}$ As a result of Dow, foreign plaintiffs now have unimpeded access to Texas courts to vindicate wrongful death and personal injury claims against corporations doing business in Texas, as long as their cases meet jurisdictional requirements.

Dow's result kindled controversy even among the justices of the Texas court, who filed seven separate opinions. ${ }^{9}$ The decision raises two questions regarding the use of forum non conveniens in international litigation in U. S. courts. First, should states be permitted to control foreign plaintiff access to their courts by departing from (or even abolishing) the federal forum non conveniens standard? This question raises a "reverse-Erie" inquiry, ${ }^{10}$ that is, whether the federal government's interest in the results of forum non conveniens decisions in international tort cases is so strong that federal courts should articulate a federal common law of forum non conveniens that binds both state and federal courts. ${ }^{11}$ If the reverse-Erie inquiry does not preclude states from developing their own forum non conveniens rules, then a second question must be addressed: Should federal courts sitting in diversity apply

"In this Comment, the term "international case" denotes a case in which, for forum non conveniens purposes, the alternate forum lies in a foreign country. Moreover, this Comment deals only with cases involving foreign plaintiffs injured abroad.

786 SW2d 674 (Tex 1990), cert denied, 111 S Ct 671 (1991).

${ }^{8}$ The court based its decision on its interpretation of $\S 71.031$ of the Texas Civil Practice and Remedies Code, which controls actions for damages for wrongful death or personal injury. The court construed the statute, originally enacted in 1913 , to mean that the state legislature gave foreign plaintiffs an absolute right to maintain personal injury and wrongful death actions in Texas. Dow, 786 SW2d at 679 . Thus, according to the court, the legislature abolished forum non conveniens for suits brought under $\$ 71.031$. Id. For an explanation of Texas forum non conveniens law and of the application of $\S 71.031$ before $D o w$, see Note, $A$ Foreign Plaintiff Has an Absolute Right to Maintain a Personal Injury Cause of Action in Texas Without Being Subject to Forum Non Conveniens Dismissal: Alfaro v. Dow Chemical Co., 20 Tex Tech L Rev 995, 1005-15 (1989).

- Four justices dissented and two wrote concurring opinions.

${ }^{10}$ Referring to Erie Railroad Co. $v$ Tompkins, 304 US 64 (1938). Under the reverseErie principle, federal common law preempts state law, even in state courts, in those areas in which federal courts have authority to develop common law rules. The principle aims to reduce forum shopping between state and federal courts. See Banco Nacional de Cuba $v$ Sabbatino, 376 US 398, 423-27 (1964); Offshore Logistics, Inc. v Tallentire, 477 US 207, 223 (1986); see also Gary B. Born and David Westin, International Civil Litigation in the United States Courts 186-87 (Kluwer, 1989).

11 See Mark D. Greenberg, The Appropriate Source of Law for Forum Non Conveniens Decisions in International-Cases: A Proposal for the Development of Federal Common Law, 4 Intl Tax \& Bus Law 155 (1986). 
state or federal forum non conveniens rules? This issue, which the United States Supreme Court has explicitly left open, ${ }^{12}$ is important because if diversity courts apply federal forum non conveniens law, a litigant could circumvent a state's version of the doctrine by removing to federal court.

While over thirty states, as a matter of state law, apply a forum non conveniens standard that closely tracks the standard federal courts apply, some states have yet to resolve the doctrine's availability and scope in their courts. Texas has placed itself at one extreme by rejecting the doctrine outright. ${ }^{13}$ Any state decision to establish a forum non conveniens rule that is either more strict or more liberal than the federal rule would implicate the questions discussed here.

This Comment addresses the two interrelated questions that Dow presents. Section I describes the history and operation of the forum non conveniens doctrine. Section II discusses some state forum non conveniens rules that diverge from the federal doctrine, including the Texas rule explicated in Dow, and the policies that support those rules. Section III examines the argument for a federal common law rule of forum non conveniens for international cases. That section concludes that states should be able to develop their own forum non conveniens rules to control foreign plaintiff access to their courts in international tort cases, even if such rules radically depart from the federal standard. Finally, Section IV argues that Erie and choice of law principles indicate that federal courts should apply state forum non conveniens law in diversity cases involving international tort claims.

\section{Federal Forum Non Conveniens Doctrine}

Forum non conveniens is a common law doctrine that allows a court in its discretion to dismiss a case within its jurisdiction on

${ }^{22}$ Gulf Oil Corp. $v$ Gilbert, 330 US 501, 509 (1947) (Court said it did not have to decide the Erie question because New York and federal forum non conveniens law were the same for purposes of that case); Williams $v$ Green Bay and W.R. Co., 326 US 549, 558-59 (1946) (Court reserved decision on whether Erie requires a federal court in a diversity case to apply the local rule of forum non conveniens); Piper, 454 US at 248 n 13 (Court left unresolved the question whether state or federal law of forum non conveniens applies in a diversity case); Chick Kam Choo v Exxon Corp., 486 US 140, 149-50 (1988) (Court did not reach and expressed no opinion on question whether under the reverse-Erie principle of federal maritime law federal forum non conveniens analysis preempts a state law forum non conveniens determination that differs significantly from the federal standard).

1s For surveys of state forum non conveniens rules, see Robertson and Speck, 68 Tex $\mathrm{L}$ Rev at 950-52 (cited in note 4); Greenberg, 4 Intl Tax \& Bus Law at 163-67 (cited in note 11); Born and Westin, International Civil Litigation at 227 (cited in note 10). 
the ground that the case can be tried more conveniently in another forum. ${ }^{14}$ Federal courts today apply the doctrine exclusively in the context of international litigation. ${ }^{15}$

In Gulf Oil Corp. $v$ Gilbert, ${ }^{16}$ the Supreme Court established a two-step procedure for deciding whether to dismiss a case on forum non conveniens grounds. Under this approach, a federal court must first determine whether an adequate alternative forum exists. If it does, the court must then decide in which forum the litigation would best serve the private interests of the litigants and the public interests of the forums. ${ }^{17}$ Gilbert directs courts to consider such private interest factors as: ease of access to sources of proof and witnesses; availability of compulsory process; possibility of view of premises; enforceability of a judgment; and "all other practical problems that make trial of a case easy, expeditious and inexpensive."18 Gilbert also directs courts to consider such public interests as: administrative ease; reasonableness of imposing jury duty on citizens of a forum that has no relation to the litigation; propriety of having the trial of a diversity case in a forum that is accustomed to applying the relevant state law; and "a local interest in having localized controversies decided at home."10 The Gilbert Court de-

${ }^{14}$ Numerous commentators have exhaustively treated the history and application of forum non conveniens doctrine. See, for example, Allan R. Stein, Forum Non Conveniens and the Redundancy of Court-Access Doctrine, $133 \mathrm{U}$ Pa L Rev 781 (1985); Edward L. Barrett, Jr., The Doctrine of Forum Non Conveniens, 35 Cal L Rev 380 (1947); Paxton Blair, The Doctrine of Forum Non Conveniens in Anglo-American Law, 29 Colum L Rev 1 (1929); Robert Braucher, The Inconvenient Federal Forum, 60 Harv L Rev 908 (1947); Comment, Considerations of Choice of Law in the Doctrine of Forum Non Conveniens, 74 Cal L Rev 565, 567-75 (1986); Note, Forum Non Conveniens and Foreign Plaintiffs in the Federal Courts, 69 Georgetown L J 1257, 1259-64 (1981). See also citations in Born and Westin, International Civil Litigation at $208 \mathrm{n} 49$ (cited in note 10). And see Margaret G. Stewart, Forum Non Conveniens: A Doctrine in Search of a Role, 74 Cal L Rev 1259 (1986).

${ }^{13}$ See In re Air Crash Disaster Near New Orleans, 821 F2d 1147, 1159 n 15 (5th Cir 1987) (en banc) ("Only when the more convenient forum is a foreign country can a suit brought in a proper federal venue be dismissed on grounds of forum non conveniens."). The only domestic applications of forum non conveniens today are in state courts (for example, dismissals in favor of other state forums or other jurisdictions within the state).

For federal domestic cases, Congress in 1948 replaced forum non conveniens with 28 USC $\S 1404(a)$, which permits a federal court to transfer a case to another federal court upon concluding the case should be tried elsewhere in the United States. 28 USC $\S 1404(\mathrm{a})$ (1988) provides: "For the convenience of parties and witnesses, in the interest of justice, a district court may transfer any civil action to any other district or division where it might have been brought." See Piper, 454 US at 253. See also Norwood v Kirkpatrick, 349 US 29, 32 (1955).

18330 US 501 (1947). See also Koster v (American) Lumbermens Mutual Casualty Co., 330 US 518 (1947) (companion case to Gilbert).

${ }^{17}$ Gilbert, 330 US at 506-09. See also Piper, 454 US at 242-44, 254-55 n 22.

18 Gilbert, 330 US at 508.

19 Id at 508-09. 
clared that unless the balance of factors strongly favors the defendant, a court rarely should disturb the plaintiff's choice of forum. ${ }^{20}$ Gilbert and its progeny leave the forum non conveniens determination to the discretion of the trial judge, whose determination is reviewable only under a deferential "clear abuse of discretion" standard. ${ }^{21}$

In Piper Aircraft Co. $v$ Reyno, ${ }^{22}$ the Court adapted the forum non conveniens doctrine to cases of foreign plaintiffs suing in U.S. courts. ${ }^{23}$ The Piper Court resolved two important issues. First, the Court held that the possibility that dismissal would change the substantive law to be applied should ordinarily not be given conclusive or even substantial weight in the forum non conveniens analysis. ${ }^{24}$ The Court reasoned that if courts overemphasized the possibility of an unfavorable change in law, dismissal might be barred even if the chosen forum were plainly inconvenient, thereby rendering the forum non conveniens doctrine "virtually useless."25 Second, the Court held that a foreign plaintiff's choice of forum deserves less deference than a domestic plaintiff's choice of a domestic forum. ${ }^{26}$

\section{State Forum Non Conveniens Rules}

A few states have established forum non conveniens standards that significantly deviate from the federal standard. Courts in Texas and Louisiana have held that the doctrine does not exist in those states' laws, at least one California court has opted not to follow Piper, and Florida has permitted forum non conveniens dismissals only in limited factual circumstances. In these states, applying state rather than federal forum non conveniens rules could mean the difference between adjudication in a U.S. court or dismissal in favor of a foreign forum. In Dow, for example, federal courts sitting in two other states had already dismissed substan-

20 Id at 508.

21 Piper, 454 US at 257. For criticism of the "clear abuse of discretion" standard in Piper, see Henry J. Friendly, Indiscretion About Discretion, 31 Emory L J 747, 748-54 (1982).

32454 US 235 (1981).

${ }^{23}$ This Comment does not discuss Gilbert and Piper in great depth, as other commentators have thoroughly analyzed these cases. For an important example of how federal courts apply forum non conveniens doctrine under Gilbert and Piper, see In re Union Carbide Corp. Gas Plant Disaster, 634 F Supp at 842.

1* Piper, 454 US at 247.

${ }^{23}$ Id at 250.

${ }^{26}$ Id at 255-56. 
tially the same suit on forum non conveniens grounds before Texas state courts heard and decided the case. ${ }^{27}$ The difference in outcome is crucial because few international cases dismissed on forum non conveniens grounds are ever actually tried abroad. ${ }^{28}$

Many of the points that the Texas Supreme Court justices argue in Dow highlight the broader policy issues underlying state decisions to establish forum non conveniens rules of a narrow or broad scope or to reject forum non conveniens altogether. These policy concerns also lie behind the choice federal courts have made to develop a forum non conveniens standard less open to international tort cases. In Dow, eighty-two Costa Rican banana plantation workers and their wives sued Dow Chemical Company and Shell Oil Company, Delaware corporations that do business in Texas. ${ }^{29}$ The workers, employees of Standard Fruit Company, claimed to have suffered serious personal injuries, including sterility, as a result of exposure to dibromochloropropane ("DBCP"), a pesticide that Dow and Shell manufactured..$^{30}$ Dow and Shell allegedly shipped several hundred thousand gallons of DBCP to Standard Fruit in Costa Rica, both before and after the U.S. Environmental Protection Agency banned DBCP's use in the United States. $^{31}$

The trial court dismissed the case on the ground of forum non conveniens. ${ }^{32}$ The intermediate court reversed the trial court's dis-

${ }^{27}$ Many of the same plaintiffs who sued in Dow had originally filed suit in 1983 in the Circuit Court for Dade County, Florida. The court subsequently removed that case to the Southern District of Florida, which dismissed the case on forum non conveniens grounds. The Eleventh Circuit affirmed the dismissal. Sibaja, 757 F2d at 1215. Another group sued in Superior Court for Los Angeles County, California, in 1985. The court removed that case to the Central District of California, which dismissed it on the basis of forum non conveniens in 1986. Aquilar v Dow Chemical Co., No 86-4753 JGD (C D Cal 1986). Another group of these plaintiffs again attempted to sue in a Florida state court, but once again, the defendants successfully removed the case to the Southern District of Florida, which dismissed on forum non conveniens grounds. Barrantes Cabalceta v Standard Fruit Co., 667 F Supp 833 (S D Fla 1987), aff'd in part, and rev'd and remanded in part on other grounds, 883 F2d 1553 (11th Cir 1989). The plaintiffs also brought suit in Harris County, Texas, in 1984. After the defendants, Dow and Shell, unsuccessfully attempted to remove that suit to federal court, the state trial court dismissed the case on the ground of forum non conveniens. But ultimately the Texas Supreme Court reversed in 1990, holding that forum non conveniens did not exist in Texas. Dow, 786 SW2d at 679.

${ }^{28}$ See note 102.

${ }^{29}$ Dow, 786 SW2d at 675.

so Id. The plaintiffs based their suit against Dow and Shell on theories of product liability, strict liability, and breach of warranty. Id at 681 (Doggett concurring).

s1 Id.

s2 Id at 675. 
missal and the Texas high court affirmed. ${ }^{33}$ The majority of the Texas Supreme Court decided that the statutory right to advance a personal injury or wrongful death claim in Texas courts precluded dismissal through forum non conveniens. ${ }^{34}$ Interpreting the relevant Texas statute, the court determined that the state legislature had abolished the doctrine. ${ }^{35}$

Justice Doggett, in a concurring opinion, contended that the real issue at stake was whether to hold multinational corporations responsible at home for their conduct abroad. Doggett stated that Texas's abolition of forum non conveniens furthered "important public policy considerations by providing a check on the conduct of multinational corporations." ${ }^{36}$ Doggett asserted that "what is really involved is not convenience but connivance to avoid corporate accountability." ${ }^{37}$ Doggett counseled against having too much concern for the welfare of multinational corporations and derided the dissenters" "xenophobic suggestion that foreigners will take over our courts."

Justice Hecht, in dissent, chided Doggett for failing to explain why the U.S. justice system should punish domestic corporations more severely for their actions in a foreign country than that country does. ${ }^{39}$ Justice Gonzalez, another Dow dissenter, argued that permitting citizens of other countries to seek redress here for injuries suffered abroad would further clog the already overburdened judicial system. ${ }^{40}$

Other states have trod a similar road. In Holmes $v$ Syntex Laboratories, Inc., ${ }^{41}$ a California court held that the state's forum non conveniens law differed from federal law in three key respects. First, California accorded much greater deference to a foreign plaintiff's choice of forum, and second, California attached more

ss Id.

ss Id at $675-79$.

ss Id at 679 . For the Dow court's statutory analysis, see note 8 .

36 Dow, 786 SW2d at 688 (Doggett concurring). But see In re Union Carbide Corp. Gas Plant Disaster, 634 F Supp at 865 (court was "well aware of the moral danger of creating [a] 'double-standard'," but recognized that the Indian interest in protecting its citizens "is significantly stronger than the local interest in deterring multinationals from exporting allegedly dangerous technology").

37 Dow, 786 SW2d at 680 (Doggett concurring). See id at 690 (Gonzalez dissenting); id at 707 (Hecht dissenting).

se Id at 680,686 (Doggett concurring).

so Id at $707 \mathrm{n} 11$ (Hecht dissenting).

40 Id at 690 (Gonzalez dissenting); see also id at 707 (Hecht dissenting).

$4156 \mathrm{Cal}$ App 3d 372 (1984). Another California court disagreed with Holmes and followed Piper in Stangvik v Shiley, Inc., 273 Cal Rptr 179 (1990), but the California Supreme Court has granted review in that case, 275 Cal Rptr 380, 800 P2d 858 (1990). 
weight to the possibility that a forum non conveniens dismissal would result in application of a law less favorable to the plaintiff. ${ }^{42}$ Finally, dismissal in California required finding a "suitable" rather than merely an "adequate" alternative forum. In California, the Holmes court held, the plaintiff's forum choice and the suitable forum requirement trump other Gilbert-style private and public interest factors. ${ }^{43}$ Thus, the Holmes court reversed a forum non conveniens dismissal that was based on the federal standard embodied in Piper.44

Some Louisiana courts have held that their state, like Texas, does not recognize the forum non conveniens doctrine. ${ }^{45}$ Moreover, the Fifth Circuit has concluded that applying federal versus Louisiana forum non conveniens rules to international cases would yield vastly different outcomes: "[o]ne case will proceed to judgment and the other will be dismissed to a foreign land." 46

Florida's forum non conveniens rules also sometimes produce distinctly different outcomes than does the federal doctrine. A Florida court may not dismiss a suit on forum non conveniens grounds unless both the plaintiff and defendant are nonresidents and the cause of action arose outside of Florida. ${ }^{47}$ In Houston $v$ Caldwell, the Florida Supreme Court noted that the state "has a fundamental interest in resolving controversies involving its citizens," and thus established a forum non conveniens rule that curtailed dismissals. ${ }^{48}$

42 Holmes, 156 Cal App 3d at 380-82.

43 Id at 378-79.

"Id at 377.

45 See, for example, Kassapas $v$ Arkon Shipping Agency, Inc., 485 S2d 565 (La App 1986) (forum non conveniens doctrine does not exist in Louisiana law). See also Fox $v$ Board of Supervisors of Lousiana State Univ. and Agricultural and Mechanical College, 576 S2d 978, 986-91 (La 1991).

${ }^{48}$ In re Air Crash Disaster Near New Orleans, 821 F2d at 1157. The court acknowledged the substantive nature of forum non conveniens, but nonetheless decided to apply federal forum non conveniens law in order to serve the federal interest in self-management and administrative independence.

${ }^{47}$ Houston v Caldwell, 359 S2d 858, 861 (Fla 1978). See also Seaboard C. L. R. Co. v Swain, 362 S2d 17 (Fla 1978); Waite v Summit Leasing \& Capital Intl Corp., 441 S2d 185 (Fla App 1983); Oboussier-Lowe v Kuehne \& Nagel (A.G. \& Co.), 531 S2d 249 (Fla App 1988).

48 Houston, 359 S2d at 861. Other states with forum non conveniens standards that are narrower than the federal rule include Connecticut and Georgia. See, for example, Picketts $v$ Intl Playtex, Inc., 215 Conn 490, 576 A2d 518 (1990) (court employed more exacting review of forum non conveniens dismissal than that which federal courts employ, but did not explicitly diverge from federal authorities); Smith $v$ Board of Regents of the Univ. System of Georgia, $165 \mathrm{Ga}$ App 565, 302 SE2d 124, 126 (1983) (forum non conveniens doctrine "has never been expressly sanctioned in Georgia courts"). 


\section{State Control of Forum Non Conveniens in State Courts}

Traditionally, states have been free to develop their own forum non conveniens law, but state courts generally have applied such laws only in domestic cases. Because of the potential expansion of international litigation in state courts, however, decisions such as the Texas legislature's (as interpreted in Dow) raise the question whether states should be able to deviate from the federal forum non conveniens doctrine. This Section argues that states should be allowed to establish their own forum non conveniens rules or to reject forum non conveniens doctrine outright. Such an option permits states to regulate the conduct of companies operating under their laws or within their borders and to decide whether to adjudicate claims based on state law.

This Comment rejects the argument, set forth by a few commentators, that federal forum non conveniens law should preempt state law in international cases. These commentators contend that the decision to dismiss such cases on forum non conveniens grounds often will affect U.S. foreign relations, a federal government concern. ${ }^{48}$ Thus, according to this argument, the federal courts may develop a federal common law rule of forum non conveniens that, under the reverse-Erie principle, would bind state as well as federal courts. ${ }^{50}$ But because a state's interest in formulating its own forum non conveniens rules outweighs the comparatively slight federal interest in international tort cases involving private litigants, a preemptive federal rule is not warranted. ${ }^{\text {s1 }}$

\section{A. State Interests in Applying State Forum Non Conveniens Law}

Strong state interests in controlling the activities of companies incorporated and operating under state laws militate against binding state courts to a federal common law of forum non conveniens.

40 See Greenberg, 4 Intl Tax \& Bus Law at 180-97 (cited in note 11). See also Born and Westin, International Civil Litigation at 227-28 (cited in note 10).

so See note 10.

81 Arguably, the act of state doctrine and the Foreign Sovereign Immunities Act, 28 USC $\S \S 1602-1611$ (1988), which apply in cases involving foreign sovereign entities as parties, prevent any real intrusion into the federal foreign affairs domain. Both are designed to apply where foreign governments, agencies, or instrumentalities are involved, and therefore where foreign government interests are explicitly implicated. Foreign relations concerns are likely to arise in cases involving official foreign parties, in contrast to cases such as those considered in this Comment, which involve only private foreign litigants and no official acts or conduct. Regarding the Foreign Sovereign Immunities Act, see Born and Westin, International Civil Litigation at 335-402 (cited in note 10). 
States should be able to determine the extent to which they will hold corporations liable for conduct abroad. The fact that international tort claims are based on state law and adjudicated under state choice of law rules bolsters the argument that states should be able to determine how readily foreign plaintiffs may advance such claims in their courts. Congress, moreover, has left state law in control of international tort actions by failing to enact a federal standard of tort liability for U.S. corporations operating abroad.

Forum non conveniens analysis generally calls upon courts to weigh the governmental interests of competing forums in the controversy being litigated. States should be free to determine their own interests in disputes involving state law claims. Furthermore, states should be free to assert an interest in opening wide their courthouse doors to foreigners, as Texas did in Dow. Texas Supreme Court Justice Doggett, concurring in Dow, noted his concern that Texans, by sitting on juries, be afforded "the opportunity to evaluate the conduct of a Texas corporation concerning decisions it made in Texas," even though the only parties allegedly hurt were foreigners. ${ }^{52}$

States may wish to hold U.S.-based firms liable for their activities in foreign countries in order to deter misconduct at home as well as abroad. Justice Doggett noted one form of misconduct spillover when he argued in Dow that the forum non conveniens doctrine embodies a "parochial perspective" that

ignores the reality that actions of our corporations affecting those abroad will also affect Texans. Although DBCP [the pesticide involved in $D o w]$ is banned from use within the United States, it and other similarly banned chemicals have been consumed by Texans eating foods imported from Costa Rica and elsewhere. ${ }^{53}$

States may also wish to avoid holding corporations to a double standard of liability-one that applies to corporate actions at home, and another governing actions abroad. ${ }^{54}$ Justice Doggett's

${ }^{82}$ Dow, 786 SW2d at 680 (Doggett concurring).

ss Id at 689 (Doggett concurring).

st See note 36 . Some federal courts have acknowledged the potential for a double standard, but have concluded that foreign forums have a more compelling interest in applying their own regulations to corporations operating within their borders. See, for example, $D e$ Melo $v$ Lederle Laboratories, 801 F2d 1058, 1064 (8th Cir 1986). The federal district court in Harrison $v$ Wyeth Laboratories, $510 \mathrm{~F}$ Supp 1, 4 (E D Pa 1980), aff'd without opinion, 676 F2d 685 (3d Cir 1982), justified its forum non conveniens dismissal on grounds that it should not impose the warning and safety requirements for drugs sold in the U.S. upon a foreign country. 
opinion in Dow was partially based on this desire to hold U.S.based multinational corporations accountable at home for their activities abroad. Doggett posited that the forum non conveniens doctrine "enables corporations to evade legal control merely because they are transnational." Dos Doggett added that the U.S. does not achieve comity by allowing its multinational corporations to follow a double standard. ${ }^{56}$ Judge Swygert, dissenting from an Eighth Circuit opinion holding that Brazil had a paramount interest in regulating the quality of drugs in that country through its own product liability laws, raised a similar point: "I cannot help observing that [the defendant] is a multinational corporation. It has chosen to do business in Brazil. When such companies do business in foreign countries they should not, by that fact, manage to evade the force of American law." "57

In such cases, courts must balance the foreign forum's interest in establishing and enforcing its own safety rules against a U.S. interest in regulating the activities of U.S.-based corporations abroad. Due to the absence of federal regulation in this area, the U.S. interest in this balance belongs to the states under whose laws corporations operate. States thus should be free to resolve independently the double standard dilemma.

Finally, states have an interest in developing their own forum non conveniens laws in order to control their courts' dockets. ${ }^{58}$ The issue of docket congestion figures prominently in the debate over forum non conveniens. Justice Gonzalez's dissent in Dow highlights the arguments for blocking the doors of U.S. courts to citizens of other countries seeking compensation for injuries suffered abroad:

[I]f the legislature fails to reinstate [the forum non conveniens] doctrine, Texas will become an irresistible forum for all mass disaster lawsuits. . . . "Bhopal"-type litigation, with little or no connection to Texas will add to our already crowded dockets, forcing our residents to wait in the corridors of our courthouses while foreign causes of action are tried. ${ }^{58}$

ss Dow, 786 SW2d at 689 (Doggett concurring).

ss Id at 687 (Doggett concurring).

87 De Melo, 801 F2d at 1065 (Swygert, sitting by designation, dissenting). The Brazilian plaintiff in De Melo filed suit in Minnesota, claiming that she was blinded by use of the drug Myambutol. The drug was manufactured, marketed, and distributed in Brazil by a wholly-owned subsidiary of Lederle's parent corporation.

${ }^{38}$ See Robertson and Speck, 68 Tex L Rev at 972 (cited in note 4).

so Dow, 786 SW2d at 690 (Gonzalez dissenting). 
Federal courts frequently raise docket congestion concerns to justify dismissing a foreign plaintiff's suit on the ground of forum non conveniens. ${ }^{60}$

States are fully competent to formulate their own solutions to the complex policy problem of weighing court access against docket congestion. ${ }^{61}$ The Dow court resolved this problem when it concluded that the state legislature had opted to accord extraordinary access to foreign plaintiffs in wrongful death and personal injury suits against Texas corporations. ${ }^{62}$

\section{B. Federal Common Law of Forum Non Conveniens}

Despite Erie's rejection of the notion of "federal general common law,"63 the Supreme Court has held that a federal common law does exist in a few areas involving "uniquely federal interests." ${ }^{64}$ Foreign relations is one area which the Court has declared an "intrinsically federal" concern, on the basis of both constitutional and federal statutory provisions. ${ }^{65}$ Some argue that forum non conveniens determinations (that is, decisions whether to adjudicate particular international suits in U.S. courts) implicate foreign relations and foreign commerce concerns, and therefore federal interests.

Courts have articulated federal common law rules for cases involving the act of state doctrine and forum selection clauses, two areas of law especially relevant to international litigation. Comparing the federal interests at stake in these two areas with those in-

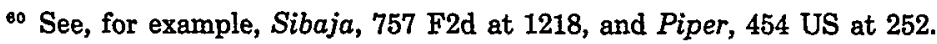

-1 The Supreme Court held in Missouri ex rel. Southern R. Co. $v$ Mayfield, 340 US 1 (1950), that in actions under the Federal Employers' Liability Act state courts may determine the availability of forum non conveniens according to their own law. The Court based its decision in part on states' interests in controlling their own dockets. Notably, the Court did not require states to apply federal forum non conveniens law in Mayfield even though the case involved a federal cause of action, and thus implicated a clear, statutorily-based federal interest.

e2 This conclusion does not undermine the argument in Section IV of this Comment that federal courts should apply state forum non conveniens law in diversity actions. Federal administrative concerns do not outweigh the substantive state interests underlying forum non conveniens. Under Erie, federal courts must apply substantive state law. See In re Air Crash Near New Orleans, 821 F2d at 1180-86 (Higginbotham concurring).

Bs Erie, 304 US at 78.

B1 Boyle v United Technologies Corp., 487 US 500, 504 (1988). See also Henry J. Friendly, In Praise of Erie-And of the New Federal Common Law, 39 NYU L Rev 383 (1964); Charles Alan Wright, Law of Federal Courts 387-97 (West, 4th ed 1983).

ss Sabbatino, 376 US at 427. See also United States v Curtiss-Wright Export Corp., 299 US 304, 318 (1936); United States v Belmont, 301 US 324, 331 (1937); Zschernig v Miller, 389 US 429, 432 (1968). 
volved in forum non conveniens reveals that forum non conveniens decisions do not implicate significant federal concerns.

\section{Act of state doctrine.}

The act of state doctrine is a common law principle that directs U.S. courts to accept the validity of public acts of foreign sovereigns within the sovereign's own territory. In Banco Nacional de Cuba v Sabbatino, the doctrine's leading modern statement, the Court held that the Cuban government was entitled (against the claims of former owners) to proceeds from the sale of sugar that the government had expropriated. ${ }^{68}$ The Court applied the act of state doctrine to the Cuban government's expropriation decree. ${ }^{67}$ The Court also held that, because of the "intrinsically federal" interest in foreign relations, the scope of the doctrine must be determined according to federal law..$^{88}$

The Sabbatino Court noted that because the act of state doctrine concerns the federal government's relations with other nations, the rule should "not be left to divergent and perhaps parochial state interpretations," and thus the Erie doctrine does not apply. ${ }^{69}$ The Court stated that "since the concept of territorial sovereignty is so deep seated, any state may resent the refusal of the courts of another sovereign to accord validity to acts within its territorial borders." dicial decisions that risked offending another sovereign could hamper executive branch negotiations related to the adjudicated matter and would probably affect relations with third countries regarding similar matters. ${ }^{71}$ A uniform, federally-dictated rule was also necessary, the Court said, to ensure predictability and thereby maintain the flow of international trade. ${ }^{72}$

os Sabbatino, 376 US at 439 . For the classic statement of the act of state doctrine, see Underhill $v$ Hernandez, 168 US 250, 252 (1897). Commentators have discussed Sabbatino extensively; see, for example, Louis Henkin, The Foreign Affairs Power of the Federal Courts: Sabbatino, 64 Colum L Rev 805 (1964). See also Richard A. Falk, The Role of Domestic Courts in the International Legal Order (Syracuse, 1964); Michael J. Bazyler, Abolishing the Act of State Doctrine, $134 \mathrm{U} \mathrm{Pa} \mathrm{L}$ Rev 325 (1986).

-7 Sabbatino, 376 US at 429-37.

68 Id at 421-27. The Court indicated that state courts are required to apply an act of state doctrine at least as deferential as federal doctrine. Id at $425 \mathrm{n} 23$. The Court recently clarified the scope of the act of state doctrine in W.S. Kirkpatrick \& Co., Inc. $v$ Environmental Tectonics Corp., Intl, 493 US 400 (1990).

- Sabbatino, 376 US at 425, citing Philip C. Jessup, The Doctrine of Erie Railroad v Tompkins Applied to International Law, 33 Am J Intl L 740 (1939).

zo Id at 432.

72 Id.

72 Id at 432-34. Referring to the specific circumstances of the Sabbatino case, the Court noted that if "the attitude of the United States courts were unclear, one buying expropri- 
Compared to cases involving the act of state doctrine, forum non conveniens decisions do not raise foreign relations concerns to the same extent. While act of state cases involve the public conduct of foreign sovereigns, forum non conveniens decisions in international tort cases only concern the conduct of private U.S. corporations. Furthermore, forum non conveniens decisions do not impinge on territorial sovereignty because such decisions do not preclude foreign decisionmaking regarding the same underlying matters. Finally, forum non conveniens determinations in private international tort cases have only an attenuated impact on international trade and thus do not present the same urgent need for predictability and uniformity as do cases such as Sabbatino. ${ }^{73}$

\section{Forum selection clause enforcement.}

The federal government's constitutional interest in foreign commerce $^{74}$ supports the argument that federal common law must govern the enforcement of forum selection clauses in international commercial contracts. ${ }^{76}$ The need for certainty in international commercial transactions presses for a federal rule enforcing forum selection clauses. No comparable need exists, however, for predictability and uniformity of forum non conveniens decisionmaking in the tort context.

In The Bremen v Zapata Off-Shore Co., the Supreme Court held that forum selection clauses in international commercial contracts are valid and enforceable unless unreasonable, unfair, or unjust. ${ }^{76}$ Most lower federal courts have determined that the Zapata rule applies in diversity suits involving substantive state law claims. ${ }^{77}$ An important rationale behind Zapata was the Court's

ated goods would not know if he could safely import them into this country." Id at 433-34.

${ }^{73}$ It is more likely that a corporation would discontinue doing business in a state which established a narrow forum non conveniens rule than that it would move overseas or shut down completely. Thus, such a state would only put its own economy in jeopardy. Federalism permits such a result.

${ }^{34}$ US Const, Art I, $\S 8$, cl 3.

75 Such clauses enable parties to a contract to choose in advance a forum in which potential disputes will be litigated or arbitrated.

76 The Bremen v Zapata Off-Shore Co., 407 US 1, 15-19 (1972). Zapata was an admiralty case, but courts have extended the holding in Zapata to non-admiralty contexts. See, for example, AVC Nederland B.V. v Atrium Investment Partnership, 740 F2d 148 (2d Cir 1984).

77 See McDonnell Douglas Corp. v Islamic Republic of Iran, 758 F2d 341, 345 n 4 (8th Cir 1985); Coastal Steel v Tilghman Wheelabrator Ltd., 709 F2d 190, 202 (3d Cir 1983); and cases cited in Born and Westin, International Civil Litigation at 185-86 (cited in note 10). But see General Engineering Corp. v Martin Marietta Alumina, Inc., 783 F2d 352 (3d Cir 1986). 
conclusion that judicial enforcement of such clauses would encourage U.S. businesses to expand overseas and would facilitate the flow of international trade. ${ }^{78}$ The Court noted that

[the elimination of] uncertainties by agreeing in advance on a forum acceptable to both parties is an indispensable element in international trade, commerce, and contracting . . . . [I]t would be unrealistic to think that the parties did not conduct their negotiations, including fixing the monetary terms, with the consequences of the forum clause figuring prominently in their calculations. ${ }^{78}$

Irregular enforcement of such clauses would undoubtedly frustrate the express intent of the parties. Furthermore, disrupting the stability of international transactions could offend foreign governments, which might perceive an economic interest of their own in preserving the integrity of their firms' bargains.

No comparable interests compel application of a federal common law rule of forum non conveniens in international tort cases. Such disputes involve neither clearly-expressed private expectations that divergent state rules might frustrate, nor federal interests. Congress has not legislated a federal liability standard for international tort actions, and foreign governments apparently have not sought to control such litigation by enacting laws that prescribe jurisdiction.

C. Foreign Relations Implications of Forum Non Conveniens Decisions

Some commentators argue that forum non conveniens decisions, like decisions in act of state doctrine and forum selection clause cases, implicate important foreign policy concerns. A U.S. court's decision to hear a dispute that could also be tried abroad, they argue, interferes with the foreign forum's interest in deciding matters of local concern. ${ }^{80}$ As two commentators put it, "[i]mposing American legal solutions on other nations, however beneficial when viewed from the perspective of individual litigants, impedes the opportunity for other legal systems to craft local solutions to their citizens' legal problems."

\footnotetext{
7s Zapata, 407 US at 8-9, 15.

7. Id at 13-14.

so See Greenberg, 4 Intl Tax \& Bus Law at 182 (cited in note 11).

-1 Birnbaum and Dunham, 16 Brooklyn J Intl L at 261-62 (cited in note 2).
} 
This proposition has two flaws. First, where courts refuse to dismiss international tort cases on forum non conveniens grounds, they do not impose solutions on other nations. Rather, the courts impose their forum's standards on U.S.-based corporations operating in or furnishing products to other nations. Such decisions directly affect only the corporate litigants. At most, these decisions might hurt the U.S. forum in which a case was tried, for example, if corporations leave a state where they receive an unfavorable judgment. ${ }^{82}$ Second, a U.S. court's decision to hear a dispute involving foreign plaintiffs need not impede the plaintiffs' government from crafting local solutions. Foreign governments can develop rules to regulate how multinational corporations operate within their territory regardless of U.S. judicial decisions. Moreover, foreign governments are free to mandate that their own courts resolve disputes concerning the conduct of multinational corporations within their borders by enacting laws prescribing jurisdiction. ${ }^{83}$ Also, foreign governments could establish substantive tort laws that create incentives for their private citizens to sue U.S.-based corporations at home rather than in the U.S.

The idea that foreign governments generally care whether U.S. courts hear cases involving their private citizens is largely speculative. ${ }^{84}$ The cases and commentary researched for this Comment reveal no instance of a foreign government protesting a judicial decision to provide private foreign plaintiffs access to U.S. courts for purposes of suing U.S. corporations.

Potentially, a foreign government might be concerned with the decision of a U.S. court in a private international dispute involving its citizens where that government has implemented a pervasive scheme regulating the industry involved in the dispute. Such regulation might indicate a governmental interest in the controversy. ${ }^{85}$ But divining such governmental interests, and then concluding that where such interests are present American adjudication would implicate foreign relations concerns, is a dubious venture.

In the Bhopal disaster litigation, for example, the district court focused on the Indian government's extensive regulation of its country's chemical industry as evidence indicating that the In-

\footnotetext{
82 See Stanguik, 273 Cal Rptr at 190.

ss Parties would litigate the effect of such laws at the jurisdictional stage, as a "jurisdiction to prescribe" case. Jurisdiction to prescribe concerns the jurisdiction of a legislature over regulation of particular conduct.

s4 See Zschernig, 389 US at 459-60 (Harlan concurring) (the argument that state court evaluations of foreign laws and governmental policies have foreign relations consequences is based entirely on speculation).

ss See Note, 69 Georgetown L J at 1278-80 (cited in note 14).
} 
dian government had a strong interest in the dispute, and therefore supporting a forum non conveniens dismissal. ${ }^{86}$ But the Indian government itself initially sued in the United States District Court for the Southern District of New York on behalf of all individual victims, suggesting that that government was not opposed to the U.S. judicial system crafting a solution to a problem that arose in India. ${ }^{87}$ The Indian government preferred that the case not be dismissed for forum non conveniens. This scenario highlights the potential difference between a foreign government's interests as construed by a U.S. court and the foreign government's actual preferences.

Some foreign governments, like the Indian government in the Bhopal case, may prefer that U.S. forums resolve international tort disputes. Given that foreign governments generally induce multinational corporations to do business in their countries, governments that appear prepared to waive their regulatory interests may be trying to have their cake (foreign investment and imports) and eat it too (relying on the U.S. to regulate corporate conduct).

Concededly, forum non conveniens decisions could affect the international trade activities of U.S. corporations. Holding a U.S.based firm liable here for its tortious conduct abroad could increase the U.S. firm's costs and handicap it vis-a-vis firms from countries with tort laws and damage awards more favorable to corporate defendants. ${ }^{88}$ Such a result might irritate foreign governments that value foreign investment more highly than health and safety concerns.

Nevertheless, it is not at all clear how much economic effect even a forum non conveniens rule as radical as Texas's might have. As Justice Doggett noted in Dow, due process and in personam limitations on jurisdiction ${ }^{88}$ still limit foreign plaintiffs' ability to

s6 In re Union Carbide Corp. Gas Plant Disaster, 634 F Supp at 863-65.

87 The Indian government expressly urged the district court to allow Indian plaintiffs to sue in the U.S., arguing that they could not receive adequate and speedy compensation in India. See Birnbaum and Dunham, 16 Brooklyn J Intl L at 257 (cited in note 2), and In re Union Carbide Gas Plant Disaster, 634 F Supp at 852, 867. For factual information regarding the case, see Note, International Mass Tort Litigation: Forum Non Conveniens and the Adequate Alternative Forum in Light of the Bhopal Disaster, $16 \mathrm{Ga} J$ Intl \& Comp L 109, 114-23 (1986). The district court ultimately dismissed the suit on forum non conveniens grounds, and the parties later settled the dispute in India.

8s See Alvin B. Rubin, Mass Torts and Litigation Disasters, $20 \mathrm{Ga} \mathrm{L} \mathrm{Rev} \mathrm{429,} 436$ (1986).

3. Courts do not consider forum non conveniens questions until after personal jurisdiction and due process requirements have been satisfied. 
flock to Texas courts, despite the state's open forum policy..$^{90} \mathrm{By}$ extension, these limitations also constrain the extent to which corporations in Texas will be held liable for tortious conduct abroad.

Some commentators have argued that imposing U.S. regulatory standards on U.S.-based multinational corporations is within the legitimate scope of this nation's foreign policy and therefore a federal government concern. ${ }^{91}$ This argument is based on the notion that the appearance of a double standard damages the United States's image abroad. If other countries believe the United States does not care if its corporations act abroad in a manner prohibited at home, that perception could strain diplomatic relations and create an unflattering reputation for U.S. exports. ${ }^{92}$ This foreign policy interest, so the argument goes, indicates that the federal government should decide whether U.S. courts will adjudicate disputes regarding the overseas conduct of U.S. corporations, and supports binding state courts to a federal common law of forum non conveniens.

Even if the federal government does have an interest in determining the extent to which the foreign conduct of U.S. corporations should be regulated, however, it does not follow that a federal common law of forum non conveniens best serves this interest. Congress could serve such putative federal interests by using its commerce power to legislate a federal standard of commercial tort liability for U.S. corporate activities abroad. Such a statutory standard would preempt state rules. Congress has not chosen to do so; thus, the federal courts should not attempt to achieve similar results by mandating a federal common law forum non conveniens rule. ${ }^{93}$

${ }^{\circ}$ Dow, 786 SW2d at 685 (Doggett concurring). As Doggett noted, "a defendant must have sufficient contacts with Texas in each lawsuit such that the assertion of jurisdiction comports with fair play and substantial justice." Id. The Texas Supreme Court had no jurisdictional issue before it in Dow, but Doggett did note that both defendants had extensive Texas contacts. Shell's world headquarters are located in Houston, and Dow conducts substantial operations from its Dow Chemical USA building in Houston. Also, Dow operates the country's largest chemical manufacturing plant within sixty miles of Houston. Id at 681. See also id at 686 .

91 See Note, Exporting Hazardous Industries: Should American Standards Apply?, 20 NYU J Intl L \& Pol 777, 782-83 (1988). For the argument that forum non conveniens dismissals remove the only consistent check on the actions of U.S. multinationals abroad, see Note, An Economic Approach to Forum Non Conveniens Dismissals Requested by U.S. Multinational Corporations, 22 Geo Wash J Intl L \& Econ 215 (1988).

22 Greenberg, 4 Intl Tax \& Bus Law at 182 (cited in note 11).

os The congressional inaction argument does not apply with equal force in the act of state doctrine and forum selection clause contexts, where clear, constitutionally-based federal interests are present. 
To the extent that forum non conveniens decisions may affect international trade, the federal government's interest in those potential effects is by no means exclusive. Many state governments are increasingly involved in directly establishing trade and investment ties with foreign sovereign instrumentalities. ${ }^{94}$ All fifty states have international trade agencies and all but seven have at least one trade office abroad. ${ }^{95}$ Growing state activity and competence in building international economic ties undercuts the argument that federal foreign commerce interests require federal control of forum non conveniens.

In short, forum non conveniens decisions do not seriously impair foreign regulatory activity, because foreign governments could establish substantive laws that create incentives for their citizens to sue in home courts, or could mandate that their own courts resolve tort disputes involving multinational corporations. The U.S. Congress, moreover, has not expressed an interest in establishing tort liability standards applicable to U.S. commercial activities abroad. Unlike act of state doctrine and forum selection clause cases, forum non conveniens decisions do not implicate constitutionally-based federal foreign relations and commerce interests strong enough to override competing state interests.

\section{Application of State Forum Non Conveniens Law in Diversity ACTIONS}

The conclusion that states should apply their own forum non conveniens rules in international cases necessarily leads to the question whether federal courts should apply federal or state forum non conveniens law in diversity suits. Federal diversity courts should apply state forum non conveniens law, this Comment argues, because forum non conveniens is substantive in nature and employs an inquiry closely aligned with choice of law analysis. If federal forum non conveniens law were to apply in diversity actions, then many domestic defendants in international tort actions filed in state courts could circumvent state forum non conveniens rules by having their cases removed to federal court. ${ }^{96}$ Because di-

24 Total state spending on international trade promotion stood at $\$ 91.9$ million in fiscal year 1990, up 58\% from fiscal year 1988. National Association of State Development Agencies, State Export Program Database 744-45 (NASDA, 1990).

${ }^{25}$ Id.

98 28 USC § 1441 (1988) provides that a defendant may remove from state to federal court any civil action of which the federal district courts have original jurisdiction, as long as no defendant is a citizen of the state in which the action was brought. Under 28 USC \& 1332(c)(1) (1988), a corporation is a citizen of the state in which it has been incorporated and the state in which the corporation has its principal place of business. 
versity of citizenship often exists in international cases, such maneuvers could successfully undermine state forum non conveniens rules that diverge from the federal standard. In Piper, the Supreme Court explicitly left unresolved the question whether, under Erie, state or federal forum non conveniens law applies in a diversity case. ${ }^{97}$ Thus, the Court did not decide whether forum non conveniens is a substantive rule of law or a procedural rule only. ${ }^{98}$ Many lower federal courts, however, have concluded that federal forum non conveniens law applies in a diversity action. ${ }^{98}$

As an empirical matter, forum non conveniens decisions invariably determine the outcomes of international tort cases and thus have the effect of substantive law. As Justice Doggett noted in Dow, "a forum non conveniens dismissal is often outcome-determinative, effectively defeating the claim and denying the plaintiff recovery." 100 Because of severe monetary limitations on recovery in foreign forums, the absence of contingent fee arrangements, and the presence of restrictive discovery rules and products liability laws, dismissals in favor of foreign forums often constitute victory for the defendants. ${ }^{101} \mathrm{Few}$ cases dismissed in the U.S. on forum non conveniens grounds ever reach trial abroad. ${ }^{102}$ Although courts and commentators routinely discuss forum non conveniens as if the issue at stake were a choice between two competing jurisdictions, in fact, the usual choice is between litigating in the United States or not at all.

This section illuminates the substantive nature of forum non conveniens decisions in international cases in two ways. First, it

${ }^{87}$ Piper, 454 US at $248 \mathrm{n} 13$.

ss Under the Erie doctrine, a federal court sitting in diversity must apply substantive state law, but federal procedural law. Erie, 304 US at 78.

92 See, for example, Sibaja, 757 F2d at 1219; In re Air Crash Disaster Near New Orleans, 821 F2d at 1159; Royal Bed and Spring Co., Inc. v Famossul Industria E Comercio De Moveis Ltda., 906 F2d 45, 50 (1st Cir 1990) (citing Sibaja); and Lapides v Doner, 248 F Supp 883, 888-92 (E D Mich 1965). See also cases cited in Born and Westin, International Civil Litigation at 226 (cited in note 10); Greenberg, 4 Intl Tax \& Bus Law at $180 \mathrm{n} 220$ (cited in note 11). But see Mizokami Bros. of Arizona Inc. $v$ Mobay Chemical Corp., 483 F Supp 201, $203 \mathrm{n} 1$ (W D Mo 1980), rev'd in part on other grounds, vacated in part and remanded, 660 F2d 712 (8th Cir 1981) (federal diversity court required to apply Missouri forum non conveniens law, but Missouri doctrine is same as the federal rule).

${ }^{300}$ Dow, 786 SW2d at 682 (Doggett concurring).

${ }^{101}$ See note 3 and accompanying text.

102 David W. Robertson, Forum Non Conveniens in America and England: "A Rather Fantastic Fiction", 103 L Q Rev 398, 409, 418-20 (1987); see also Irish Natl Ins. Co. v Aer Lingus Teoranta, 739 F2d 90, 91 (2d Cir 1984) (court said the claim would never be pursued in the alternate forum because of that forum's severe damage award limitations; to weigh convenience in this context would amount to a "legal charade"). 
distinguishes forum non conveniens decisions from the operation of 28 USC $\S 1404(\mathrm{a})$, a procedural rule permitting transfer of venue, which replaced the common law of forum non conveniens for domestic litigation in federal courts. Second, this section argues that forum non conveniens determinations and choice of law determinations, which are unquestionably substantive, are closely analogous.

A. Contrast Between Forum Non Conveniens and Section 1404(a)

Forum non conveniens doctrine and $\S 1404$ (a) have the same historical roots, but unlike $\S 1404$ (a) transfers, forum non conveniens decisions have outcome-determinative effects upon litigation. Under the rule of Van Dusen $v$ Barrack, ${ }^{103}$ when a federal court transfers a case to another federal venue under $\S 1404(\mathrm{a})$, the transferee court must apply the substantive state law (including choice of law rules) that the transferor court would have applied. ${ }^{104}$ Thus, a change of venue does not affect the law applied to the case and is therefore only a procedural maneuver that will not alter a dispute's outcome.

A dismissal on forum non conveniens grounds in an international case, on the other hand, will most likely significantly affect the outcome of a suit. First, the dismissed case may never be tried at all. An important distinction between $\S 1404$ (a) and forum non conveniens is that the former only allows a court to transfer a case to another domestic forum, whereas forum non conveniens enables a court to dismiss a suit altogether. ${ }^{105}$ As a practical matter, forum non conveniens dismissals are outcome-determinative because foreign courts, unlike domestic courts receiving $\S 1404$ (a) transfers, rarely adjudicate suits dismissed from U.S. courts. ${ }^{106}$ As one federal court acknowledged, "only an outright dismissal with prejudice could be more 'outcome determinative' than a conditional dismissal to a distant forum in a foreign land."107

Second, a forum non conveniens dismissal can change the applicable law. Even if the foreign forum eventually tries the dismissed suit, that forum will apply its own choice of law rules, po-

10s 376 US 612 (1964).

${ }^{104}$ Id at $639,643-44$.

105 Many federal courts, though, use their discretion to attach conditions to forum non conveniens dismissals in international cases, sometimes providing that a suit may be refiled in the U.S. court if the foreign forum will not entertain the suit.

${ }_{108}$ Robertson, $103 \mathrm{~L} \mathrm{Q} \mathrm{Rev} \mathrm{at} \mathrm{409,} \mathrm{419-20} \mathrm{(cited} \mathrm{in} \mathrm{note} \mathrm{102).}$

${ }^{207}$ In re Air Crash Disaster Near New Orleans, 821 F2d at 1156. 
tentially leading to application of a different law and therefore a different outcome than if a U.S. court had tried the case. In both of these ways, therefore, a forum non conveniens dismissal in favor of a foreign forum is not merely a "change of courtrooms."

Because a forum non conveniens dismissal affects the suit's substantive outcome, allowing a federal diversity court to dismiss a case that a state court applying state forum non conveniens law would retain (or vice-versa) violates the Erie doctrine. In Van $\mathrm{Du}$ sen, the Court prohibited circumvention of substantive state rules via transfer; accordingly, federal courts should not be able to ignore substantive state forum non conveniens laws by applying federal forum non conveniens law. ${ }^{109}$ As a consequence, a federal court deciding a diversity action in Texas after Dow, for example, would not have the option of entertaining forum non conveniens motions in international wrongful death or personal injury suits.

\section{B. Relationship Between Choice of Law and Forum Non Conveniens}

The important role that choice of law considerations play in the forum non conveniens inquiry, as well as the close relationship between choice of law and forum non conveniens analyses, suggest that forum non conveniens decisions, like choice of law decisions, turn on substantive considerations. Gilbert identified choice of law considerations as one of the public interest factors that courts should weigh in the forum non conveniens analysis. ${ }^{110}$ Later courts have taken this suggestion to heart and have emphasized choice of law considerations in their forum non conveniens decisions, dismissing cases in which those courts have found that foreign law should apply. ${ }^{111}$

\footnotetext{
${ }^{108}$ Van Dusen, 376 US at 639. Additional evidence that forum non conveniens law is substantive may be that denial of a forum non conveniens motion is not a collateral order subject to immediate appeal as a final judgment under 28 USC $\S 1291$. Van Cauwenberghe $v$ Biard, 486 US 517 (1988). The Court stated in Van Cauwenberghe that consideration of the Gilbert factors when weighing whether a particular forum is so inconvenient to a defendant as to warrant dismissal entangles courts in the merits of the underlying dispute. Id at 528 . See also Coastal Steel v Tilghman Wheelabrator Ltd., 709 F2d 190, 195 (3d Cir 1983) (the Gilbert factors "are considerations going to the merits of the case and requiring assessment of the substantive issues in the litigation").

${ }^{108}$ See Stein, $133 \mathrm{U} \mathrm{Pa} \mathrm{L}$ Rev at 821 (cited in note 14).

110 Gilbert, 330 US at 509.

${ }^{111}$ See In re Union Carbide Corp. Gas Plant Disaster at Bhopal, 634 F Supp at 866 (need to apply foreign law is a significant consideration in a forum non conveniens motion); De Melo, 801 F2d at 1064 (probability that Brazilian law would govern the litigation strongly supported forum non conveniens dismissal); Chambers ' $v$ Merrell-Dow
} 
In addition, the public interest balancing that forum non conveniens analysis requires closely resembles the governmental interest balancing that choice of law rules typically require. ${ }^{112}$ When assessing the Gilbert "public interest factors," courts must determine the substantive concerns of the alternative forums with respect to the controversy. ${ }^{113}$ Yet the flexible forum non conveniens doctrine affords judges more discretion than choice of law analysis. Federal appellate courts review forum non conveniens decisions under a weak abuse of discretion standard, while choice of law determinations are fully reviewable. This may help to explain why, as some commentators have noted, forum non conveniens decisions are often choice of law decisions in disguise. ${ }^{114}$ As one commentator has stated, the forum non conveniens issue in international products liability cases turns less on administrative convenience than on the propriety of imposing U.S. standards of liability on particular foreign transactions. ${ }^{115}$

In Klaxon Co. $v$ Stentor Electric Mfg. Co., the Supreme Court declared that, under Erie, state choice of law rules must apply in federal diversity suits in order to promote decisional uniformity among state and federal courts within a state and thereby avoid forum shopping. ${ }^{116}$ The Court stated that any divergence among federal courts in different states is attributable to the federal system, which permits states to pursue policies that differ from their neighbors'.117 Federal courts, the Klaxon court added, should not

Pharmaceuticals Inc., 35 Ohio St 3d 123, 519 NE2d 370, 379 (1988); Barrantes Cabalceta v Standard Fruit Co., 667 F Supp 833, 838-39 (S D Fla 1987); Dahl v United Technologies Corp., 632 F2d 1027, 1032 (3d Cir 1980); Calavo Growers of Cal. v Belgium, 632 F2d 963, 967 (2d Cir 1980); Schertenleib v Traum, 589 F2d 1156, 1165 (2d Cir 1978); Farmanfarmaian v Gulf Oil Corp., 588 F2d 880, 881 (2d Cir 1978). Regarding the close relationship between forum non conveniens and choice of law, see-Stein, $133 \mathrm{U} \mathrm{Pa} \mathrm{L}$ Rev at 818-22 (cited in note 14); Weintraub, 16 Brooklyn J Intl L at 233-34 (cited in note 3).

112 See Born and Westin, International Civil Litigation at 225-26 (cited in note 10); Restatement (Second) of Conflict of Laws § 6 (1971) (choice of law principles). When a state such as Texas rejects forum non conveniens altogether, it is the state legislature's rejection that may be analogous to choice of law decisionmaking.

${ }^{113}$ See Stein, $133 \mathrm{U}$ Pa L Rev at 784-85, 821-22 (cited in note 14); Comment, $74 \mathrm{Cal} \mathrm{L}$ Rev at 591-94 (cited in note 14); Paul K. Speck, Forum Non Conveniens and Choice of Law in Admiralty: Time for an Overhaul, $18 \mathrm{~J}$ Marit L \& Comm 185, 207-08 (1987) (forum non conveniens analysis and choice of law analysis overlap so significantly that courts often treat them as virtually identical).

${ }^{114}$ See Stein, $133 \mathrm{U} \mathrm{Pa} \mathrm{L} \mathrm{Rev} \mathrm{at} 822$ (cited in note 14); see generally Speck, $18 \mathrm{~J}$ Marit L \& Comm at 207-08 (cited in note 113).

${ }_{118}$ Comment, $74 \mathrm{Cal} \mathrm{L} \mathrm{Rev} \mathrm{at} 598$ (cited in note 14).

${ }^{116}$ Klaxon Co. $v$ Stentor Electric Mfg. Co., 313 US 487, 496 (1941). See Wright, Law of Federal Courts at 364-70 (cited in note 64).

117 Klaxon, 313 US at 496. 
thwart local policies by enforcing an independent general law of conflict of laws. ${ }^{118}$

These same arguments apply in the forum non conveniens context. Federal courts (and defendants, via removal to federal courts) should not thwart substantive state policies regarding the extent to which firms will be held liable for conduct abroad. Hence, the principle behind the Klaxon rule militates in favor of applying state forum non conveniens law in federal diversity actions.

Thus, because forum non conveniens determinations often turn on a choice of law decision, and because of the close identity between choice of law and forum non conveniens analysis, federal courts should apply state forum non conveniens law in diversity actions.

\section{Conclusion}

Courts use the forum non conveniens doctrine as a tool for controlling foreign plaintiff access to forums in the United States. States have strong interests in deciding when to adjudicate actions involving corporations incorporated and doing business under state law. Thus, states must be able to apply their own forum non conveniens rules in their courts, or to reject the doctrine altogether. The opposing argument for a federal common law rule of forum non conveniens fails for lack of significant foreign relations implications. Furthermore, because forum non conveniens law has a substantive impact upon international litigation, federal diversity courts should, under Erie, apply state forum non conveniens rules. As a policy matter, it is unclear whether strict or liberal forum non conveniens laws best advance U.S. foreign economic interests. The best solution, therefore, is for the states to serve as "laboratories of federalism" in which their courts and legislatures may experiment with a range of options. ${ }^{110}$

218 Id.

119 See Connecticut Light and Power Co. v Federal Power Comm'n, 324 US 515, 530 (1945). 